\title{
STUDIES ON THE BIOGENESIS AND METABOLISM OF NOREPINEPHRINE IN PATIENTS WITH PHEOCHROMOCYTOMA*
}

\author{
By ALBERT SJOERDSMA, LEMUEL C. LEEPER, $\dagger$ LUTHER L. TERRY, AND \\ SIDNEY UDENFRIEND
}

(From the Section of Experimental Therapeutics and Laboratory of Clinical Biochemistry, National Heart Institute, Bethesda, Md.)

(Submitted for publication June 4, 1958; accepted September 4, 1958)

Discovery of the physiologic importance of norepinephrine and its role as a chemical mediator in the sympathetic nervous system is of relatively recent origin (1). Studies in experimental animals have led to rapid advances in our knowledge of the biochemical processes involved in the formation and metabolism of this amine. It seemed important to confirm and extend these studies in man and to establish their clinical significance. Such investigations are diffcult to perform because of the small amounts of norepinephrine normally found in the blood and urine and the fact that fresh human tissue is not easily obtained for enzymatic study. Patients with pheochromocytoma provided a satisfactory solution to this problem since the tumor usually produces large amounts of norepinephrine and is a tissue which can be studied enzymatically after surgical removal. During the past five years, a sufficient number of patients with pheochromocytoma as well as specimens of tumor and urine were made available to enable us to demonstrate a number of the catalysts and intermediates involved in the formation and metabolism of norepinephrine in man and to estimate the rate of its synthesis by the tumors.

\section{MATERIALS AND METHODS}

Specimens of acidified urine, and frozen plasma and tumor were received from many sources for assay of catecholamines. However, most of the biochemical studies to be reported were done on seven patients. ${ }^{1}$ Tumors

* Part of the work presented here has been used by Lemuel C. Leeper in a thesis in partial fulfillment of the degree of Doctor of Philosophy, Department of Chemistry, Georgetown University, Washington, D. C., April, 1958.

$\dagger$ Present address: Riverton Laboratories, Inc., 852 Clinton Avenue, Newark, N. J.

1 They were hospitalized at the National Naval Medical Center, Bethesda, Md.; Georgetown University Hospital, Washington, D. C.; Walter Reed Army Medical Center, from these patients were placed in cracked ice or frozen upon surgical removal for subsequent chemical and enzymatic studies.

Chemical compounds. L-norepinephrine-bitartrate, Lepinephrine-bitartrate and 3,4-dihydroxybenzoic acid were obtained from commercial sources. The 3,4-dihydroxy-DL-phenylalanine-3- $\mathrm{C}^{14}$ and DL-epinephrine-2- $\mathrm{C}^{14}$ bitartrate were supplied by Nuclear Chemical and Instrument Company. The 3,4-dihydroxyphenylethylamine1- $\mathrm{C}^{14}-\mathrm{HBr}$ and 3-methoxy-4-hydroxybenzoic acid were synthesized in this laboratory. The 3-methoxy analogues of norepinephrine, epinephrine and dihydroxyphenylethylamine were supplied as the hydrochlorides by Dr. Bernard Witkop, National Institute of Arthritis and Metabolic Diseases.

Measurement of catecholamines in tissue and urine. Tissues were homogenized in $0.1 \mathrm{~N} \mathrm{HCl}$ and 15 per cent trichloroacetic acid $(1: 2: 2)$. The protein precipitate was removed by centrifugation and the supernatant solution extracted with water-saturated ether to remove the trichloroacetic acid. Catecholamines were extracted from acid-hydrolyzed urine by the method of von Euler and Orwen (2). The colorimetric method of von Euler and Hamberg (3) was used to measure epinephrine and norepinephrine in tissue extracts when the concentrations of the amines were adequate. Optical density was measured with a Beckman DU spectrophotometer. In some tumor extracts and in urine extracts, a modification (4) of the fluorometric procedure of Lund (5) was used, and the fluorescent product assayed using an Aminco-Bowman spectrophotofluorometer. The method of WeilMalherbe and Bone (6) was used for determination of catecholamines in plasma. Although this method may not be as specific as other fluorometric procedures, it has a high order of sensitivity and when properly used is satisfactory in diagnosing pheochromocytoma.

Isolation and assay of methoxy analogues of catecholamines. Tumors were homogenized in a Waring blendor in six volumes of $0.01 \mathrm{~N} \mathrm{HCl}$. Portions of the homogenates were adjusted to $\mathrm{pH} 10.0$ by addition of a saturated solution of sodium carbonate and extracted three times with five volumes of $n$-butanol. To the combined butanol extracts were added an equal volume of heptane and 0.2 volume of $0.5 \mathrm{~N} \mathrm{HCl}$. After shaking, the aqueous layer was evaporated to dryness in vacuo and the residue

Washington, D. C.; and Southwest Foundation for Research and Education, San Antonio, Tex. 
taken up in $10 \mathrm{ml}$. of methanol. The methanol was then evaporated under a stream of nitrogen to $0.4 \mathrm{ml}$. and portions were subjected to chromatography on Whatman No. 1 paper using two different solvents. The chromatograms were allowed to develop overnight in either isopropanol-5 per cent $\mathrm{NH}_{3}(8: 2)$, or butanolacetic acid-water $(8: 1: 1)$. After drying in air the chromatograms were sprayed with a freshly prepared solution of 2,6-dichloroquinone chloroimide ( 0.05 per cent $\mathrm{w} / \mathrm{v}$ in ethanol) followed by borate buffer, $\mathrm{pH} 9.0$ (7). Solutions of the authentic compounds in $0.01 \mathrm{~N}$ $\mathrm{HCl}$ and material eluted from the chromatograms were assayed fluorometrically (activation at $280 \mathrm{~m} \mu$ and fluorescence at $330 \mathrm{~m} \mu$ ).

The enzyme which methylates the 3 -hydroxy group of norepinephrine and its congeners is relatively nonspecific. In studies on 0 -methylation by tumor slices the conversion of 3,4-dihydroxybenzoic acid to 3-methoxy-4hydroxybenzoic acid was utilized since the latter compound is more easily isolated and assayed than is the 3-methoxy metabolite of norepinephrine. 3-Methoxy-4-hydroxybenzoic acid was isolated from incubation mixtures after acidification ( $\mathrm{pH} 2.0$ ) and salt saturation by shaking twice with $20 \mathrm{ml}$. portions of ethyl acetate. The solvent phase was concentrated in vacuo to $0.3 \mathrm{ml}$. and transferred to Whatman No. 3 paper for chromatography. The chromatograms were developed with isopropanol-5 per cent $\mathrm{NH}_{3}(8: 2)$ and sprayed with the phenol reagent as described above. The 3-methoxy acid formed was compared with authentic compound ( $\operatorname{Rf} 0.35$ ).

Isolation and assay of radioactive norepinephrine. The procedure for isolation of norepinephrine- $C^{16}$ from tumor slices and homogenates was the same as described previously for adrenal tissue (8). Extracts of urine prepared according to the procedure of von Euler and Orwen (2) were concentrated in vacuo and carried through the same procedure. Milligram-quantities of carrier norepinephrine were added to measured aliquots of the isolated norepinephrine- $\mathrm{C}^{16}$ and the catecholamine was then crystallized to constant specific activity and measured according to the procedure described by Udenfriend and Wyngaarden (4).

Enzymatic studies on tumor. All steps in preparing tissue slices and homogenates were carried out at $3^{\circ} \mathrm{C}$. within two hours after removal of the tumors. Homogenates were prepared in a Potter homogenizer using isotonic $\mathrm{KCl}$ (one part tissue to two parts $\mathrm{KCl}$ ). Tumor slices were prepared with a Stadie tissue slicer. Dopa decarboxylase activity was measured manometrically as described by Schales (9) and monoamine oxidase activity by a method described previously (10). The conditions used for incubation in studies with radioactive precursors of norepinephrine and in methylation of catechols by tumor slices are described in the appropriate tables.

TABLE I

Catecholamines in plasma, urine and tumor*

\begin{tabular}{|c|c|c|c|c|c|c|c|c|c|}
\hline $\begin{array}{l}\text { Case } \\
\text { no. }\end{array}$ & Age & Sex & Time & $\underset{\text { NE† }}{\text { Plasma }}$ & $\begin{array}{l}\text { Urinary } \\
\mathrm{NE}+\mathrm{E} \ddagger\end{array}$ & $\underset{\mathrm{NE}}{\text { Tumor }}$ & $\underset{\mathrm{E} \delta}{\text { Tumor }}$ & $\begin{array}{l}\text { Tumor } \\
\text { weight }\end{array}$ & $\begin{array}{l}\text { Location } \\
\text { (area) }\end{array}$ \\
\hline \multirow[t]{2}{*}{1} & \multirow[t]{2}{*}{6} & \multirow[t]{2}{*}{$\mathbf{M}$} & & $\begin{array}{l}\mu g . / L . \\
68.5\end{array}$ & & $\begin{array}{l}m g . / G m . \\
9.8\end{array}$ & $\begin{array}{l}m g, / G m . \\
I\end{array}$ & $\begin{array}{r}G m . \\
22\end{array}$ & Right suprarenal \\
\hline & & & $\begin{array}{l}11 / 57 \\
\text { Postop. }\end{array}$ & 13.3 & $\begin{array}{r}2,200 \\
825\end{array}$ & 5.0 & I & 15 & $\begin{array}{l}\text { Neck } \\
\text { Site undetermined }\end{array}$ \\
\hline 2 & 34 & $F$ & $6 / 55$ & 60.8 & & 8.0 & 1.7 & 160 & Left suprarenal \\
\hline 3 & 8 & $\mathrm{~F}$ & $\begin{array}{l}9 / 55 \\
\text { Postmortem }\end{array}$ & 65.6 & & $\begin{array}{l}4.0 \\
3.5 \\
1.8\end{array}$ & $\begin{array}{l}\text { I } \\
\text { I } \\
\text { I }\end{array}$ & $\begin{array}{l}36 \\
30 \\
20\end{array}$ & $\begin{array}{l}\text { Right suprarenal } \\
\text { Left suprarenal } \\
\text { Thorax }\end{array}$ \\
\hline \multirow[t]{2}{*}{4} & \multirow[t]{2}{*}{6} & \multirow[t]{2}{*}{$\mathrm{F}$} & $10 / 55$ & 16.8 & & \multirow[t]{2}{*}{$\begin{array}{l}1.4 \\
0.2\end{array}$} & \multirow[t]{2}{*}{$\underset{\mathrm{I}}{0.2}$} & \multirow[t]{2}{*}{$\begin{array}{l}1.4 \\
1.7\end{array}$} & \multirow[t]{2}{*}{$\begin{array}{l}\text { Right suprarenal } \\
\text { Bifurcation of aorta }\end{array}$} \\
\hline & & & $12 / 55$ & 9.9 & & & & & \\
\hline \multirow[t]{2}{*}{5} & \multirow[t]{2}{*}{33} & \multirow[t]{2}{*}{$\mathrm{F}$} & $12 / 55$ & 22.0 & 1500 & \multirow{2}{*}{$\begin{array}{l}3.5 \\
1.8\end{array}$} & \multirow{2}{*}{ I } & \multirow{2}{*}{$\begin{array}{l}20 \\
22\end{array}$} & \multirow{2}{*}{$\begin{array}{l}\text { Right suprarenal } \\
\text { Left suprarenal }\end{array}$} \\
\hline & & & Postop. & 5.7 & 190 & & & & \\
\hline 6 & 41 & $\mathbf{M}$ & $5 / 56$ & & 1,000 & 1.9 & I & 46 & Right suprarenal \\
\hline .7 & 44 & $\mathbf{F}$ & $9 / 57$ & & 1,900 & 9.8 & 2.1 & 430 & Right suprarenal \\
\hline
\end{tabular}

* Specimens of tumor were received in seven additional cases and in five of these, acidified urine specimens were also submitted. The tumors contained 0.5 to $7.1 \mathrm{mg}$. per $\mathrm{Gm}$. norepinephrine; only one tumor contained a significant amount of epinephrine, $5.8 \mathrm{mg}$. per $\mathrm{Gm}$. The values for epinephrine plus norepinephrine in urine were: 430, 820, 1,600, 1,600 and $3,000 \mu \mathrm{g}$. per day.

$\dagger$ Usual range is 3 to $6 \mu \mathrm{g}$. per L. norepinephrine and $<1.0 \mu \mathrm{g}$. per L. epinephrine. Epinephrine values were within normal limits in all cases wherein plasma assays were done.

\pm Expressed as norepinephrine-equivalent. Usual range is 50 to $200 \mu \mathrm{g}$. per day.

$\S$ I, insignificant amount, i.e. $<5$ per cent of norepinephrine value. 


\section{EXPERIMENTAL RESULTS}

Since the clinical features of pheochromocytoma are well known, only the chemical findings in our cases will be presented. ${ }^{2}$

Measurement of catecholamines in plasma, urine and tumor

Since the original report by Engel and von Euler (12) of increased urinary excretion of norepinephrine in two patients with pheochromocytoma, the diagnostic value of chemical measurements of norepinephrine and epinephrine in plasma and urine has been demonstrated repeatedly. Large amounts of norepinephrine and often epinephrine also have been found in the tumors. Our experience is summarized in Table I. In this group of patients, the tumors contained norepinephrine as the predominant amine. This was true also of those located in the suprarenal areas.

\section{Studies on biosynthesis of norepinephrine}

The pathway for biosynthesis of norepinephrine in the body is now considered to be as shown in Figure 1. Although this metabolic sequence was first postulated in 1939 by Blaschko (13), convincing evidence could not be obtained even in experimental animals until the advent of isotopic tracer techniques and chromatographic methods for separating the three amines, 3,4-dihydroxyphenylethylamine (dopamine), norepinephrine and epinephrine. It has now been shown in animals that phenylalanine- $\mathrm{C}^{14}$ (which gives rise to tyrosine), tyrosine- $\mathrm{C}^{14}$, 3,4-dihydroxyphenylalanine- $\mathrm{C}^{14}$ (dopa) and dopamine- $\mathrm{C}^{14}$ are precursors of adrenal norepinephrine and epinephrine. It is usually assumed that the formation of norepinephrine precedes that of epinephrine. Langemann (14) and Burger and Langemann (15) have reported that chromaffin tissue is rich in dopa decarboxylase. Little is known of the other cellular catalysts in the biosynthetic pathway.

$A$. In vitro. Portions of tumor-tissue from the patients in Cases 2, 5 and 6 were fortified with all the probable cofactors and incubated with radioactive dopa and dopamine. As shown

2 Cases No. 1, 3, 4 and 5 (see Table I above) have been reported by Cone, Allen and Pearson (11).

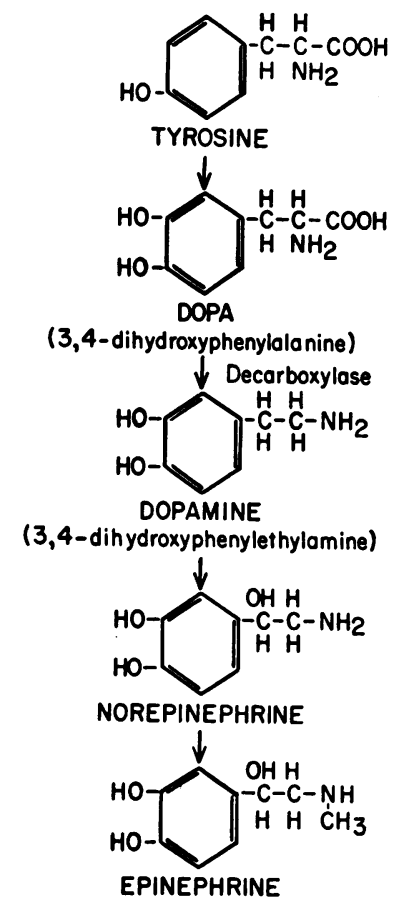

Fig. 1. The Catecholamine Pathway of Tyrosine Metabolism

in Table II, significant radioactivity appeared in norepinephrine isolated from the incubation mixtures in all experiments. Measurement of dopa decarboxylase activity in two tumors (Cases 5 and 6) gave values of 8,360 and $2,500 \mu \mathrm{g}$. dopa metabolized per Gm. per hour. This is a very high order of activity and is comparable to that found in guinea pig kidney, an extremely rich source of the enzyme.

TABLE II

Formation of norepinephrine from $C^{14}$-labeled precursors by pheochromocytoma in vitro

\begin{tabular}{llrrr}
\hline \hline $\begin{array}{l}\text { Case } \\
\text { no. }\end{array}$ & C14 substrate* & $\begin{array}{c}\text { Radioactivity } \\
\text { of substrate }\end{array}$ & \multicolumn{2}{c}{$\begin{array}{c}\text { Activity in isolated } \\
\text { norepinephrine }\end{array}$} \\
\hline & & $c p m$ & $c p m / \mu M$ & total cpm \\
2a $\dagger$ & Dopa & $2,500,000$ & 3,300 & 21,100 \\
5a & Dopamine & 800,000 & 652 & 4,300 \\
6a & Dopamine & 800,000 & 1,367 & 10,400 \\
6b & Dopamine & 800,000 & 840 & 6,400 \\
\hline
\end{tabular}

* $\mathrm{C}^{14}$ compound incubated with $667 \mathrm{mg}$. tumor in air for one and one-half to three hours. In addition to substrate, the incubation mixtures contained $1 \mu \mathrm{M}$ diphosphopyridine nucleotide (DPN), $10 \mu \mathrm{M}$ nicotinamide, $2 \mu \mathrm{M}$ adenosine triphosphate (ATP), $250 \mu \mathrm{M} \mathrm{MgCl}_{2}, 0.2 \mathrm{ml}$. $0.5 \mathrm{M}$

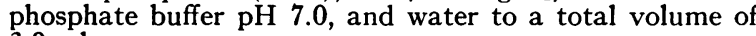
$3.0 \mathrm{ml}$.

$\dagger \mathrm{a}$, homogenates; $\mathrm{b}$, slices. 
TABLE III

Urinary excretion of norepinephrine-C ${ }^{14}$ after administration of dopamine-C $C^{14}$ *

\begin{tabular}{cccr}
\hline \hline & \multicolumn{3}{c}{ Activity in norepinephrine } \\
\cline { 2 - 4 } $\begin{array}{c}\text { Collection } \\
\text { periods }\end{array}$ & Case 1 & Case 5 & Case 6 \\
\hline hrs. & $c p m / \mu M$ & $c p m / \mu M$ & $c p m / \mu M$ \\
24 & & 2,960 & 2,450 \\
48 & & 185 & 370 \\
72 & & 80 & 120 \\
96 & & & trace \\
& & & \\
4 & 9,440 & & \\
8 & 2,220 & & \\
12 & 1,000 & & \\
24 & 785 & & \\
& 525 & & \\
\hline
\end{tabular}

* $5 \times 10^{6} \mathrm{cpm}$ administered intravenously.

B. In vivo. Additional proof of the precursor relationship of dopa and dopamine to norepinephrine in man was obtained by studies on four patients (Cases 1, 4, 5 and 6). The radioactive precursors were dissolved in $20 \mathrm{ml}$. of physiological $\mathrm{NaCl}$ solution and administered intravenously to these patients over a period of 10 minutes. In Case 4 a significant amount of radioactivity was found in norepinephrine isolated from urine collected during the first 24 hours after administration of $5 \mu \mathrm{c}$. of dopa- $\mathrm{C}^{14}$ (1.2 mg.) but quantitative studies were not carried out. The results of studies in three patients given $5 \mu \mathrm{c}$. of dopamine- $\mathrm{C}^{14}(1.2 \mathrm{mg}$.) are shown in Table III. In the studies on Patients No. 5 and 6, 24 hour collections of urine were made since a relatively slow rate of norepinephrine turnover analogous to that previously found in animal adrenals (4) was anticipated. Although large amounts of radioactivity were incorporated into the norepinephrine, the specific activity fell at such a rapid rate as to make estimates of turnover difficult using 24 hour collection periods. In a subsequent study in Case 1, urine collections were obtained at four hour intervals in order to obtain more precise information on turnover rate. It can be seen that a high degree of labeling of norepinephrine occurred within the first four hours. The specific activity of the urinary norepinephrine declined precipitously during the first 12 hours with a slower rate of decline occurring thereafter. The changes in specific activity observed between 48 and 72 hours in the first two experiments and after 12 hours in the third ex- periment most likely are indicative of the turnover rate of norepinephrine in the tumors. With proper assumptions, a half-life value for tumor norepinephrine may be calculated which is of the order of 8 to 12 hours. The initial, very rapid turnover phase is not easily explained. It may signify norepinephrine of nonpheochromocytoma origin, such as sympathetic nerve. This possibility is currently being investigated in normal individuals. It may also represent norepinephrine made by the tumor which does not mix with the norepinephrine stored in the tumor. The amount of dopamine administered in these experiments did not result in any marked increase in the synthesis of norepinephrine since the daily urinary excretion of norepinephrine did not change significantly during the experiments.

Total urinary $\mathrm{C}^{14}$ excretion following administration of dopamine-C $\mathrm{C}^{14}$ was measured in one experiment (Case 6). Seventy-five per cent of the radioactivity was excreted in the first 24 hours, four per cent in the second 24 hours and less than one per cent in two subsequent days.

Although norepinephrine can be converted to epinephrine, the process was not found to be reversible in the calf adrenal gland (8). Since it has been demonstrated that a system for the demethylation of certain $\mathrm{N}$-methyl amines does exist in the animal tissues (16), the following experiment was designed to investigate the possible conversion of epinephrine to norepinephrine in man. Five $\mu \mathrm{c}$. (2.78 mg.) of radioactive epinephrine were infused intravenously over a period of several hours in Patient No. 7 and 24 hour urine collections were obtained starting at the beginning of the infusion. The norepinephrine from the first day's collection was isolated and recrystallized and its radioactivity measured. The results obtained are shown in

TABLE IV

Comparison of epinephrine and dopamine as precursors of norepinephrine in vivo

\begin{tabular}{lcc}
\hline \hline C14 compound & $\begin{array}{c}\text { Total } \\
\text { counts } \\
\text { administered }\end{array}$ & $\begin{array}{c}\text { Activity in } \\
\text { isolated } \\
\text { norepinephrine* }\end{array}$ \\
\hline Epinephrine & $5,000,000$ & $\mathrm{cpm} / \mu M$ \\
Dopamine & $5,000,000$ & $<24$ \\
\hline
\end{tabular}

* First 24 hour urine.

† Average of three experiments cited in Table III. 
Table IV; a comparison is made with the findings following dopamine- $\mathrm{C}^{14}$ adminstration. It is obvious that there was little if any demethylation of epinephrine to form norepinephrine.

\section{Studies on the metabolism of norepinephrine}

Little was known of the fate of norepinephrine and epinephrine in the body until recently. The studies of von Euler and Luft (17) and Goldenberg, Serlin, Edwards and Rapport (18) showed clearly that only a small percentage of norepinephrine given intravenously is excreted in the urine. In 1957, Armstrong, McMillan and Shaw (19) reported the isolation of 3-methoxy-4-hydroxymandelic acid from human urine and showed that it was a major product of norepinephrine metabolism. Axelrod (20) then showed that the 3-hydroxy position of norepinephrine can be methylated by animal tissues; he also presented evidence (21) that $o$-methylation followed by oxidative deamination is the major pathway of metabolism in rats. Studies in this laboratory (22) using a partially purified preparation of monoamine oxidase have shown conversion of norepinephrine to 3,4-dihydroxymandelic acid and $o$-methylnorepinephrine (normetanephrine) to 3methoxy-4-hydroxymandelic acid. o-Methylation of many catechol compounds has been demonstrated $(20,22)$ in vitro, including 3,4-dihydroxymandelic acid.

From this work one would surmise that the major portion of norepinephrine in patients with

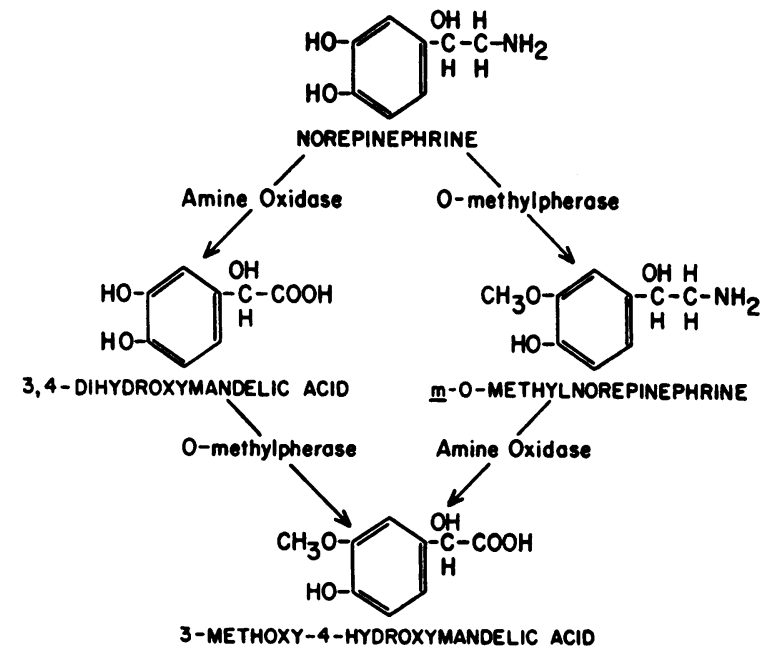

Fig. 2. The Major Routes of Metabolism of NOREPINEPHRINE
TABLE V

Chromatographic behavior of methoxy analogues of catecholamines and the compound extracted from four pheochromocytomas

\begin{tabular}{cccc}
\hline \hline & \multicolumn{2}{c}{ Rf } & \\
\cline { 2 - 3 } Compound & $\begin{array}{c}\text { Isopropanol- } \\
5 \% \mathrm{NH}_{\mathbf{3}} \\
(8: 2)\end{array}$ & $\begin{array}{c}\text { Butanol- } \\
\text { acetic } \\
\text { acid-water } \\
(8: 1: 1)\end{array}$ & $\begin{array}{c}\text { Color } \\
\text { with } \\
\text { phenol } \\
\text { reagent }\end{array}$ \\
\hline 1 & $0.62-0.66$ & 0.31 & Blue \\
$\mathrm{NMN}^{*}$ & 0.65 & 0.30 & Blue \\
$\mathrm{ME}^{*}$ & 0.80 & 0.28 & Blue \\
$\mathrm{MD}^{*}$ & 0.77 & 0.40 & Tan-pink
\end{tabular}

* Abbreviations correspond to the 3-methoxy analogues of norepinephrine (NMN), epinephrine (ME), and 3,4dihydroxyphenylethylamine (MD).

pheochromocytoma is metabolized by the pathways shown in Figure 2. It is of considerable importance to determine which pathway predominates and which, if either, may limit the physiologic actions of norepinephrine. The following studies were designed to answer some of these questions.

$A$. In vitro. A preliminary report of some of these findings has been presented elsewhere (23). Portions of four tumors were studied for the presence of methoxy-substituted catecholamines as described in the section on methods. The results of these studies, summarized in Table V, indicate that all the tumors contained a butanolextractable base identical with normetanephrine (NMN) as shown by its $\mathrm{Rf}$ values and color obtained with the phenol reagent and ninhydrin. In several instances the areas corresponding to NMN on the chromatograms obtained with isopropanol- $\mathrm{NH}_{3}$ were eluted and rechromatographed with butanol-acetic acid. The $\mathrm{Rf}$ values obtained were again identical with those of authentic NMN. The tumor in Case 7, which contained epinephrine as well as norepinephrine, was found to contain two additional phenolic substances, Compounds 2 and 3 . Compound 2 appeared on the chromatograms between NMN and the methoxy analogue of epinephrine (ME) and gave a bluishgreen color with the phenol reagent, unlike that of the three available standards. Compound 3 exhibited $\mathrm{Rf}$ values and color (tan-pink) identical with those of the methoxy analogue of dopamine (MD).

The areas on the chromatogram corresponding to Compounds 1,2 and 3 were eluted with 0.01 
$\mathrm{N} \mathrm{HCl}$ and their fluorescence characteristics were compared with authentic NMN, ME and MD, using the Aminco-Bowman spectrophotofluorometer. All three componds and the reference standards exhibited maximal activation at 280 $\mathrm{m} \mu$ and maximal fluorescence at $330 \mathrm{~m} \mu$. Further evidence for the identity of Compound 1 with NMN was obtained by eluting it from the chromatogram and subjecting it to distribution between equal volumes of $0.5 \mathrm{M}$ borate buffer $\mathrm{pH}$ 10 , and $n$-butanol. Analyses were carried out spectrophotofluorometrically. The distribution coefficients (concentration in butanol/concentration in aqueous) obtained for Compound 1 and NMN were 0.43 and 0.44 , respectively, whereas values for $M E$ and $M D$ were 4.0 and 6.1. One tumor (Case 7), subjected to quantitative assay for NMN using a combination of paper chromatography and spectrophotofluorometry, was found to contain about $25 \mu \mathrm{g}$. per $\mathrm{Gm}$.

Further studies revealed that the tumor (Case 7) is capable of converting catechols to their 3methoxy analogues. However, the tissue could do this only when presented with the activated form of methionine, S-adenosylmethionine (see Table VI). It is not known whether the tumor can synthesize S-adenosylmethionine in vivo. We have also found that many organ tissues which normally contain norepinephrine such as heart, brain and adrenal gland are capable of methylating catechol compounds under these

TABLE VI

Assay for o-methylating enzyme in pheochromocytoma

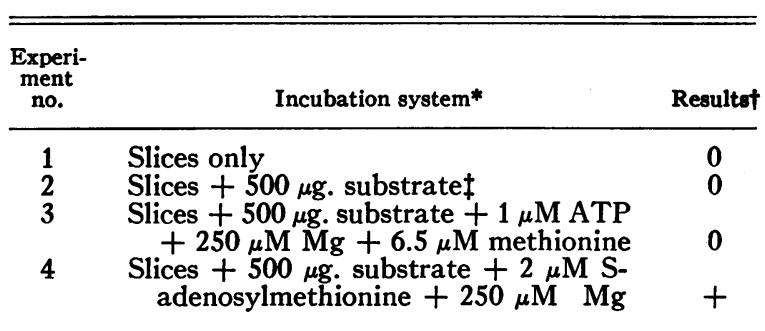

* Incubation was for three hours in air at $37^{\circ} \mathrm{C}$. In addition to the components listed, each beaker contained $0.3 \mathrm{ml}$. of $0.5 \mathrm{M}$ phosphate buffer, $\mathrm{pH} 7.7$, and water to make a final volume of $3.0 \mathrm{ml}$. The tissue slices weighed $500 \mathrm{mg}$. in each instance.

$\dagger$ The $o$-methyl acid was extracted from the incubation mixture with ethyl acetate after acidification and salt saturation. The extract was then evaporated to small volume $(0.5 \mathrm{ml}$.) and chromatographed for $o$-methyl compounds as described under "Methods."

‡ Substrate was 3,4-dihydroxybenzoic acid. circumstances. The same tumor (Case 7) was also found to have considerable monoamine oxidase activity with $600 \mu \mathrm{g}$. serotonin being metabolized per $\mathrm{Gm}$. per hour.

$B$. In vivo. While the measurement of 3methoxy-4-hydroxymandelic acid is a useful means of diagnosing pheochromocytoma (19), another possible approach is revealed by the findings of LaBrosse, Axelrod and Sjoerdsma (24) in two of our patients. Making quantitative use of paper chromatography, it was found that Patients 1 and 7 were excreting about $20 \mathrm{mg}$. of 3-methoxy-4hydroxymandelic acid per day but also 10 to 30 mg. of normetanephrine when the norepinephrine excretion was approximately $2 \mathrm{mg}$. per day.

\section{DISCUSSION}

It would appear from these studies that the pathway for biosynthesis of norepinephrine in pheochromocytoma is the same as that shown previously in animal adrenal gland. The chemical disorder in patients with this tumor may, therefore, be thought of as a disturbance in the metabolism of tyrosine. Preliminary studies suggest that a lower fasting plasma tyrosine level may exist in these patients than in normals (25).

Two of the reactions in the biosynthesis of norepinephrine which were demonstrated here were the decarboxylation of dopa and the side chain hydroxylation of dopamine. Other studies in this laboratory have shown that pheochromocytoma is more active in hydroxylating dopamine than are various animal tissues, including adrenal gland (26). Recent reports by Weil-Malherbe (27) and McMillan (28) indicate that some pheochromocytomas may produce dopamine as the predominant catecholamine. It is possible that there are tumors which produce only dopamine because of an inability to convert it to norepinephrine. Since dopamine is a relatively weak pressor agent, such a tumor might erroneously be termed "nonfunctioning." Furthermore, a dopamine producing tumor may not be detected by some of the bioassay and chemical procedures which are carried out on blood and urine. A simple chemical assay on the tumor itself would reveal this, however. In this respect it is now advisable and feasible to carry out chemical analyses of many secreting tumors which are still being classified only by histological methods. 
The finding of the methoxy analogue of norepinephrine (normetanephrine) in the tumors is the first demonstration of this amine in human tissues. Although procedures for measuring urinary metabolites of norepinephrine are still only semiquantitative, it would appear from studies in pheochromocytoma that the two major metabolites in man are normetanephrine and 3-methoxy4-hydroxymandelic acid. Development of satisfactory methods for measuring these substances will have many applications, including alternate means for diagnosing pheochromocytoma.

The rapid turnover rate of norepinephrine in the three patients with pheochromocytoma (halflife of about 10 hours) is in sharp contrast to the relatively slow turnover in animal (and presumably human) adrenal gland (half-life of several days) (4). The patients (Cases 1, 5 and 6) studied had tumors which contained only norepinephrine, indicating probable neural origin. This may signify similar rapid turnover of the amine in sympathetic nerves. Considering the fact that only a small percentage of norepinephrine entering the blood is excreted in the urine $(17,18)$, it can be concluded from the amounts of norepinephrine in the urines and tumors in Cases 5 and 6 that release of an amount equivalent to the entire tumor pool over a period of 24 hours would be required to produce the amount of urinary norepinephrine found daily in each case. This is entirely consistent with the experimentally determined turnover rates for tumor norepinephrine. On the other hand, it is obvious that Patient No. 7 could not have survived if the entire tumor content of norepinephrine (approximately $4,200 \mathrm{mg}$.) were released into the blood every day. The urinary excretion of catecholamines in this case was only slightly greater than in the previous cases. A slower rate of turnover must be postulated in this instance. It may be more than coincidence that the tumor in Case 7 was the largest $(430 \mathrm{Gm}$.) in this series and also contained epinephrine. The other relatively large tumor (Case 2, 160 $\mathrm{Gm}$.) also contained a considerable amount of epinephrine. The same correlation between size of tumor and presence of epinephrine can be seen in the data of von Euler and Ström (29). We would like to speculate that these large tumors originate from the adrenal gland and retain its properties of storage, slow turnover and ability to produce epinephrine. This may account for their growth to a much larger size before the amounts of catecholamines which they secrete are sufficient to produce clinical manifestations.

\section{SUM MARY}

1. Chemical studies on seven patients with pheochromocytoma are presented.

2. Studies with $\mathrm{C}^{14}$-labeled precursors in vitro and in vivo corroborate present concepts of the biogenesis of norepinephrine from dihydroxyphenylalanine and dihydroxyphenylethylamine. Enzymes involved in the biogenesis and metabolism of norepinephrine were demonstrated in the tumors.

3. The 3-methoxy analogue of norepinephrine (normetanephrine) was found in each of four pheochromocytomas studied. This is the first demonstration of this amine in a human tissue.

4. Preliminary evidence is cited which indicates that the two major urinary metabolites of norepinephrine in patients with this tumor are normetanephrine and 3-methoxy-4-hydroxymandelic acid. Measurements of these compounds may afford an alternate means of diagnosis.

5. Estimations of norepinephrine turnover rate in three patients suggest a relatively short halflife in some pheochromocytomas as compared to animal adrenal glands.

6. Some implications of these findings are discussed.

\section{ACKNOWLEDGMENT}

The authors sincerely appreciate the cooperation of many physicians who have referred material for chemical studies. We wish to acknowledge particularly the collaboration of Capt. T. E. Cone, Bethesda, Md.; General T. W. Mattingly and Dr. J. J. Canary, Washington, D. C.; Dr. J. W. Goldzieher, San Antonio, Tex.; and S. R. Hill, Birmingham, Ala. The technical assistance of Miss Consuelo Garcia and Mr. William King is appreciated.

\section{REFERENCES}

1. von Euler, U. S. Noradrenaline; Chemistry, Physiology, Pharmacology, and Clinical Aspects. Springfield, Ill., Charles C Thomas, 1956.

2. von Euler, U. S., and Orwen, I. Preparation of extracts of urine and organs for estimation of free and conjugated noradrenaline and adrenaline. Acta physiol. scand. 1955, 33, Suppl. 118, 1. 
3. von Euler, U. S., and Hamberg, U. Colorimetric estimation of noradrenaline in the presence of adrenaline. Science 1949, 110, 561.

4. Udenfriend, S., and Wyngaarden, J. B. Precursors of adrenal epinephrine and norepinephrine in vivo. Biochim. biophys. Acta 1956, $20,48$.

5. Lund, A. Simultaneous fluorimetric determinations of adrenaline and noradrenaline in blood. Acta pharmacol. (Kbh.) 1950, 6, 137.

6. Weil-Malherbe, H., and Bone, A. D. The adrenergic amines of human blood. Lancet 1953, 1, 974 .

7. Bray, H. G., and Thorpe, W. V. Analysis of phenolic compounds of interest in metabolism in Methods of Biochemical Analysis, David Glick, Ed. New York, Interscience Publishers, Inc., 1954, vol. I, p. 27.

8. Rosenfeld, G., Leeper, L. C., and Udenfriend, S. Biosynthesis of norepinephrine and epinephrine by the isolated perfused calf adrenal. Arch. Biochem. 1958, 74, 252.

9. Schales, O. Amino acid decarboxylases of animals in Methods in Enzymology, Sidney P. Colowick and Nathan O. Kaplan, Eds. New York, Academic Press Inc., 1955, vol. II, p. 195.

10. Sjoerdsma, A., Smith, T. E., Stevenson, T. D., and Udenfriend, S. Metabolism of 5-hydroxytryptamine (serotonin) by monoamine oxidase. Proc. Soc. exp. Biol. (N. Y.) 1955, 89, 36.

11. Cone, T. E., Jr., Allen, M. S., and Pearson, H. A. Pheochromocytoma in children. Report of three familial cases in two unrelated families. Pediatrics 1957, 19, 44.

12. Engel, A., and von Euler, U. S. Diagnostic value of increased urinary output of noradrenaline and adrenaline in phaeochromocytoma. Lancet 1950, 2, 387.

13. Blaschko, H. The specific action of $l$-dopa decarboxylase. J. Physiol. (Lond.) 1939, 96, $50 P$.

14. Langemann, $H$. Enzymes and their substrates in the adrenal gland of the ox. Brit. J. Pharmacol. 1951, 6, 318.

15. Burger, M., and Langemann, $H$. Bestimmungen von Adrenalin und Noradrenalin sowie von Decarboxylase- und Aminoxydase-Aktivitäten in Zellfraktionen von Phäochromocytomen. Klin. Wschr. 1956, 34, 941.
16. Axelrod, J. The enzymatic demethylation of ephedrine. J. Pharmacol. exp. Ther. 1955, 114, 430.

17. von Euler, U. S., and Luft, R. Noradrenaline output in urine after infusion in man. I rit. J. Pharmacol. 1951, 6, 286.

18. Goldenberg, M., Serlin, I., Edwards, T., and Rapport, M. M. Chemical screening methods for the diagnosis of pheochromocytoma. Amer. J. Med. 1954, $16,310$.

19. Armstrong, M. D., McMillan, A., and Shaw, K. N. F. 3-Methoxy-4-hydroxy-D-mandelic acid, a urinary metabolite of norepinephrine. Biochim biophys. Acta 1957, 25, 422.

20. Axelrod, J. O-Methylation of epinephrine and other catechols in vitro and in vivo. Science 1957, 126, 400.

21. Axelrod, J., Inscoe, J. K., Senoh, S., and Witkop, B. O-Methylation, the principal pathway for the metabolism of epinephrine and norepinephrine in the rat. Biochim biophys. Acta 1958, 27, 210.

22. Leeper, L. C., Weissbach, H., and Udenfriend, S. Studies on the metabolism of norepinephrine, epinephrine and their 0 -methyl analogues by partially purified enzyme preparations. Arch. Biochem. 1958, 77, 417.

23. Sjoerdsma, A., King, W. M., Leeper, L. C., and Udenfriend, S. Demonstration of the 3-methoxyanalog of norepinephrine in man. Science 1958, $127,876$.

24. LaBrosse, E. H., Axelrod, J., and Sjoerdsma, A. Urinary excretion of normetanephrine by man. Fed. Proc. 1958, 17, 386.

25. Waalkes, T. P., and Udenfriend, S. A fluorometric method for the estimation of tyrosine in plasma and tissues. J. Lab. clin. Med. 1957, 50, 733.

26. Leeper, L. C. Studies on the biosynthesis and inactivation of norepinephrine and epinephrine. $\mathrm{Ph} . \mathrm{D}$. Thesis, Department of Chemistry, Georgetown University, Washington, D. C., 1958.

27. Weil-Malherbe, H. Phaeochromocytoma, catechols in urine and tumour tissue. Lancet 1956, 1, 282.

28. McMillan, M. Identification of hydroxytyramine in a chromaffin tumor. Lancet 1956, 2, 284.

29. von Euler, U. S., and Ström, G. Present status of diagnosis and treatment of pheochromocytoma. Circulation 1957, 15, 5. 